African Crop Science Journal by African Crop Science Society is licensed under a Creative Commons Attribution 3.0 Uganda License. Based on a work at www.ajol.info/ and www.bioline.org.br/cs DOI: http://dx.doi.org/10.4314/acsj.v25i2.5

\title{
ECONOMIC PERFORMANCE OF COMMUNITY BASED BEAN SEED PRODUCTION AND MARKETING IN THE CENTRAL RIFT VALLEY OF ETHIOPIA
}

Y.A. TEBEKA, E. KATUNGI ${ }^{1}$, J.C. RUBYOGO ${ }^{2}$, D. SSERUNKUUMA and T. KIDANE ${ }^{3}$

College of Agricultural and Environmental Sciences, Makerere University, P. O. Box 7062 Kampala, Uganda

${ }^{1}$ International Center for Tropical Agriculture, P. O. Box 6247, Kampala, Uganda

${ }^{2}$ Pan African Bean Research Alliance, International Center for Tropical Agriculture, C/O Selian Agricultural

Research Institute, P. O. Box 2704, Arusha, Tanzania

${ }^{3}$ Ethiopian Agricultural Research Institute, P. O. Box 2003, Ethiopia

Corresponding author: e.katungi@cgiar.org

(Received 8 June, 2016; accepted 8 May, 2017)

\begin{abstract}
Limited access to seed of improved varieties is an impediment to agricultural productivity in sub-Saharan Africa. Researchers in the national and international agricultural research systems have been piloting a community based seed multiplication and marketing enterprises (CBSME) model, as an alternative to the formal seed systems, in order to increase availability and accessibility to quality seed of improved common bean (Phaseolus vulvaris L.) varieties by smallholder farmers. The objective of this study was to assess the profitability of CBSME as an enterprise for seed production and analyse factors that influence farmers' decisions to participate in it as seed producers or buyers of seed. Gross margins were computed to assess value addition at farm level; while Tobit and multivariate probit models used to respectively, analyse determinants of participation in community based seed multiplication enterprise and its use by producers as a seed source. The community based seed multiplication enterprises were found to be profitable, generating US\$792 as gross margins and accessible to farmers for the bean seed, along other seed sources, i.e. formal and informal seed systems. These three seed production and delivery models competed at farm level, but complemented each other in terms of reaching users in different social groups and locations. Community based seed multiplication enterprises as sources of seed were used by farmers located in rural areas and those in farmer organisations/cooperatives. However, seed production through this model is concentrated closer to urban areas, where individual seed producers are easily linked to the formal seed system. This, however, makes the marketing of seed reliant on big buyers for redistribution among remote farming communities.
\end{abstract}

Key Words: Community bean seed multiplication, Ethiopia, improved varieties, seed systems

\section{RÉSUMÉ}

L'accès limité aux semences de variétés améliorées est un obstacle à la productivité agricole en Afrique subSaharienne. Les cherheurs dans les systems nationaux de recherches agricoles sont entrain de tester des modèles d'entreprises communautaires de multiplication et de commercialisation (CBSME); comme une alternative aux systèmes semenciers formels, dans le but d'accroître la disponibilité et l'accessibilité aux semences de qualité de l'haricot commun (Phaseolus vulvaris L.) par les petits producteurs. L'objectif de cette étude était d'évaluer la profitabilité de CBSME comme une entreprise de production des semences et d' analyser les facteurs qui influencent les décisions des producteurs à y participer en tant que producteurs et acheteurs de semences. Les marges brutes 
étaient calculées pour évaluer la value ajoutée au niveau de l'exploitation agricole, tandis que les modèles de Tobit et multivarié de Probit étaient utilisés respectivelement, pour analyser les determinants de participation à l'entreprise de multiplication des semences communautaires et son utilisation par les producteurs comme une source de semences. Les entreprises de multiplication des semences communautaires ont été identifiées rentables, générant des marges brutes de 792 US dollars et les semences de l'haricot sont accessibles aux producteurs, comparées à d'autres sources de semences, c'est-à-dire les systèmes semenciers formel et informel. Ces trois modèles de production et de distribution des semences se rivalisent à l'échelle de l'exploitation agricole, mais se complètent en atteignant differents groupes sociaux d'utilisateurs dans de localités différentes. Les entreprises de multiplication des semences communautaires comme sources de semences, étaient utilisées par les producteurs situés dans les milieux ruraux et ceux en organisations/coopératives paysannes. Néamoins, la production des semences à travers ce modèle est plus concentrée dans les zones urbaines, où les producteurs individuels de semences entrent facilement en contact avec le système semencier formel. Ceci, cependant met la commercialisation de la semence en étroit contact avec les grands acheteurs pour la redistribution des semences entre les communautés paysannes isolées.

Mots Clés: Multiplication de semence communautaire d'haricot, Ethiopie, variétés améliorées, systems semenciers

\section{INTRODUCTION}

The world's demand for common bean (Phaseolus vulvaris L.) is increasing due to population growth and improvement in economies, especially in developing countries. This growth in bean demand provides trade opportunities for small scale growers to commercialise their bean production and improve their livelihoods. However, common bean production is highly susceptible to a number of biotic and abiotic constraints, notably, drought, diseases and low soil fertility (Buruchara et al., 2011), which necessitate research to enhance adaptability of the crop to the ever increasing environmental stresses.

The major bean research thrust in SubSaharan Africa has been on developing bean varieties that are adapted to multiple constraints, as a strategy to reduce yield loss due to biotic and abiotic stresses. However, like other self-pollinated crops, access and use of research derived new bean varieties by the target beneficiaries is constrained by the fact that commercial private seed companies are hesitant to invest in seed business because seed demand is uncertain.

In Ethiopia, the government owned seed enterprise have for long been operating below capacity, and thus unable to supply adequate quantities of bean seed and/or provide a diversity of bean varieties (Rubyogo et al.,
2010). Besides, the Ethiopian Seed Enterprise (ESE) had difficulty in accessing remote areas, supplied in big packs that are less affordable to the poor farmers, charged high prices and failed to supply seed on time during sowing period (Crowford et al., 2003; Rubyogo et al., 2007; Langyintuo et al., 2010; Katungi et al., 2011).

These challenges that limited access to bean seed of new improved varieties by the poor farmers prompted researchers in the Pan Africa Bean Research Alliance (PABRA-see http://www.pabra-africa.org) to explore alternative options to strengthen the linkage between formal and informal seed systems. In 2003, the "Wider Impact Seed Dissemination approach" was initiated by CIAT and the Bean Research Programme at Melikassa Agriculture research center (MARC) to address barriers that constrained access and utilisation of improved bean varieties in Ethiopia (Teshale et al. 2006; Rubyogo et al., 2010, Buruchara et al., 2011).

This approach embraced a collaborative arrangement that builds on varied organisational strengths, to shift from a centralised to a decentralised and pluralistic seed systems for improved access to quality bean seed (Buruchara et al., 2011).

New seed production and/or delivery models: small packs and community based seed multiplication models (CBSME) were 
introduced and piloted under the auspices of the Tropical Legumes Project implemented through PABRA framework (Buruchara et al., 2011; Habte et al., 2011; Rubyogo et al. 2016). These models are not mutually exclusive, but complement each other in ensuring that farmers access seed of new bean varieties of their choice.

The small (1-2 kg) pack approach enables farmers to purchase quality seed of new varieties and evaluate them for productivity and profitability; thereby reducing uncertainty about the superiority of the bean variety. The poor households can afford small packs and multiply the variety on their farms to accumulate the desired quantities of seed.

The CBSME builds on the advantages of the informal and formal seed systems to increase seed availability, accessibility and affordability by small holder farmers. The basic characteristics of CBSME are farmers' ownership of the enterprise, and their responsibility for independently operating it alongside the commercial system (Thijssen $e t$ al., 2008).

Unlike the formal seed system, the CBSME has a decentralised structure, which allows farmers to avail seed in different places by involving farmers' unions, cooperatives, peasant associations and other NGOs. This enables the timely availability of seed for sowing in remote communities often not served by formal seed systems.

Since the introduction of the small pack approach and CBSME, the Ethiopian Agriculture Research Institute, through its bean research programmes at MARC, Regional agricultural Research Organisations (RARO) and CIAT, have invested significantly towards developing CBSME into specialised commercial sustainable enterprises. For example, individual farmers and farmer groups have been trained in seed production techniques, including plant protection, postharvest handling and business skills (Rubyogo et al., 2016). Further support came in the form of breeder/basic seed loans, awareness creation and popularisation of varieties through mass media, on-farm demonstrations and participatory variety selection models, to create demand (Rubyogo et al., 2016).

Although there is considerable information about CBSME in Ethiopia, little is known about its economic performance in terms of value added to the farmer's investment and its use by the local non-participating farmers as their source of seed. This study was conducted to assess the profitability of CBSME in the Central rift valley of Ethiopia and examine factors that facilitate or constrain farmers' participation in the same. The study also investigates the use of CBSMEs by local farmers as their source of seed, factors that influence their choice of seed source and evaluates whether CBSME complements the formal seed systems.

\section{MATERIALS AND METHODS}

Study area. The study was conducted in the Central Rift Valley of Ethiopia, which is located between 1500 and 2300 metres above sea level. The dominant climate in the area falls between the longest tropical and sub-tropical agroclimate zones. The annual mean rainfall of the study area ranges between 90 and $1990 \mathrm{~mm}$ in two rainy seasons, meher (the shortest), and kiremt (the largest), respectively. Common bean is the second most produced crop, after maize, being used as food and cash crop by smallholders (Rubyogo et al., 2011). It is cultivated during the Kiremt season, which starts in June and ends in September.

Data sources and sampling procedures. The study used primary data, complemented by secondary data from Oromiya Regional State official website, woreda (district) offices (i.e. Boset, Adamitulu judocombolcha and Shalla), Ethiopian Seed Enterprise, Central Statistics Agency, MARC and CIAT. A multi stage sampling procedure was used to cost effectively select households for inclusion in the analysis. First, three woredas (The number of woredas was limited to three due to budget 
limitations) were randomly selected from the lists of all woredas in Central Rift Valley of Ethiopia. The woredas were: Boset, Adamitulu judocombolcha and Shalla, with a respective population of 34,$888 ; 26,582$ and 21,598 , making a total of 83,068 people in 13,398 households. All these woredas were important producers of the three types of common bean; red, white and ranger. From each woredas, two kebeles (each equivalent of a village) were then randomly selected from a list of all kebeles in the woreda, making a total of 6 randomly selected kebeles. Households for the interview were selected randomly using a random start from a list of households in each kebele, obtained from kebele leaders. Because seed multipliers were few (less than 10 in a kebele), all seed multipliers in each kebele were identified with the help of kebele leaders and purposively included in the survey. A sample of 195 farming households, 50 of who were seed multipliers were surveyed in the six kebeles.

Primary data were collected through a survey of households conducted during kiremt season of 2012/13 by MARC in collaboration with CIAT. Well-trained enumerators conducted face to face direct interviews with household heads or their representatives, using a semi-structured pretested questionnaires. Data were gathered on: socioeconomic characteristics of the decision maker (such as age, education, gender and occupation) and those of the household (household size, wealth assets), type and sources of seed planted in the study season as well as detailed bean production inputs, their respective prices, quantities harvested and plot characteristics. Information was also gathered on bean grain and seed marketing, as well as the market characteristics including distance from the farm to seed source. Furthermore, information on the community was gathered through focus group discussions organised in each of the selected kebeles.

Data analysis. Descriptive as well as econometric techniques were used to analyse the data in the Stata software, Version 13. Gross margin analysis was used to calculate the profitability of seed production, which is essential in understanding whether farmerbased seed system can be promoted as a profitable business as well as its prospect for expansion to new producers. Econometric analysis was then applied to identify factors that influenced the farmers' decision to participate in CBSMEs, their intensity of participation as well as those that have influence on the choice of seed source used by farmers at planting.

Gross margins. Gross margins obtained by seed multipliers involved in the CBSME and those who produced bean as grain were computed for each household as the difference between total revenue and total costs according to Upton (1964);

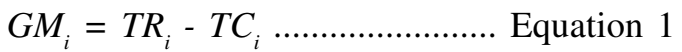

Where:

$G M_{i}=$ the gross margin, $T R_{i}=$ the total

revenue and $T C_{i}=$ the total cost of production incurred by farmer $i$.

Revenue and total costs were normalised at hectare level. Total revenue was computed as the sum of the market value of the bean grain sold as seed or grain and the imputed value of bean crop residues. Although less common, bean crop residues in Ethiopia can either be used to feed livestock or sold to other farmers. For households where bean crop residues were not sold, the average market value of bean crop residues of US $\$ 0.025$ per $\mathrm{kg}$ was used following Funte et al. (2009). Total variable costs included the cost of inputs (i.e. seed, fertiliser, labour, pesticides), costs related with storage, transport and rented land. Since family labour is not traded, it was valued at the average wage rate for hired labour in each kebele and ranged from USD.1.85-3.15. 
Estimation of farmer participation. In modeling the farmer's participation in CBSME, we followed Amare et al. (2012) and assumed that under imperfect market conditions and uncertainty, farmers allocate their resources to agricultural enterprises based on the objective of maximising the expected profits. The expected profit from seed multiplication is denoted by $\pi_{p}$; while $\pi_{N p}$ is the expected profit farmer $i$ receives by not participating in CBSME but uses the resources in the production of grain. The intensity of participation in CBSME by farmer $i$, is observable when $\pi_{P}>\pi_{N P}$ and will remain unobserved if $\pi_{P} \leq \pi_{N P}$.

Participation in CBSME, measured as the amount of land in hectares allocated to seed multiplication enterprise in 2012/13 is a twostep voluntary decision making process. In the first step, the individual decides on whether or not to participate in CBSME. Then, the individual decides on the amount of land to allocate to seed multiplication conditioned on a positive decision to participate in the first step. This means that participation in seed multiplication is a censored variable observed as zero at the left corner and continuous above zero. From previous studies, censored limited dependent variables are commonly tackled using either Tobit or two stage Heckman model (Chukwuji and Ogisi, 2006; Akinola et al., 2010; Bernard et al., 2010). The basic difference between Tobit and Heckman models is the assumption each makes towards the simultaneity of decision to participation and level of participation.

The Tobit model assumes that participation and level of participation, in our case, the amount of land allocated to seed multiplication, are made simultaneously. On the other hand, the two stage Heckman model assumes that the two decisions are made separately and that the decision to participate influences the decision on the level of participation. This can cause a selection bias, leading results to be inconsistent, if not accounted for in the econometric analysis.

To check for possible presence of selection bias, we first estimated the two stage Heckman model. The Heckman model uses the inverse mill's ratio $(\lambda)$ to detect and control for the selection bias. The inverse mill's ratio is derived from the first stage and included in the second stage to test and control for selection bias. The lack of significance of the mills ratio provided evidence of no selection bias. Thus, a Tobit specification was considered to be more appropriate for analysing the data than the two stage Heckman model. According to Gujarati (2004), a Maximum Likelihood (ML) Estimator which is used in Tobit model is much more efficient than the estimators used in two stage Heckman model.

Following Gujarati (2004), the statistical model underlying a Tobit can be expressed as:

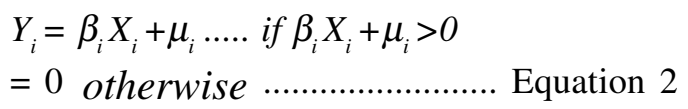

Where:

$Y_{i}=$ the observed amount of land allocated to seed multiplication enterprises, $X_{i}=$ a vector of explanatory variables; and $\beta_{i}=$ a vector of coefficients to be estimated.

The vector $\mu_{i}$ contains the unobserved random error terms that are assumed to be independently and normally distributed with zero mean and constant variance. According to Tobin (1958), the expected value of participation and the amount of land allocated to seed multiplication enterprises across all observations can be estimated as:

$E\left(Y_{i}\right)=X \beta F(z)+\sigma f(z) \ldots \ldots$ Equation 3

Where:

$\mathrm{z}=X \beta / \sigma, F(\mathrm{z})=$ the cumulative distribution function, $f(\mathrm{z})=$ the value of derivative of the 
normal curve at a given point, $\mathrm{z}=$ the $\mathrm{Z}$-score for the area under normal curve, $\beta=$ a vector of Tobit maximum likelihood estimates, and $\sigma$ $=$ the standard error of the error term.

Each explanatory variable in the Tobit model has two effects; the effect on the probability to participate in CBSME and the effect on the intensity of participation. A McDonald and Moffitt decomposition technique (Maddala, 1983) was used to decompose the total effect of a change in the independent variable on a dependent variable, into its effect on the probability to participate (i.e. adopt) and the effect on the intensity of participation. Accordingly, the change in the probability of participating in CBSME as independent variable

$X_{i}$ changes is estimated as:

$$
\frac{\partial F(z)}{\partial X_{i}}=f(z) \frac{\beta_{i}}{\sigma}
$$

Similarly, the change in intensity of participation defined as the amount of land allocated to seed production business with respect to change in an explanatory variable $\left(X_{1}\right)$ among adopters is estimated by:

$$
\begin{aligned}
& \frac{\partial E\left(Y \mid Y_{i}^{*}>0\right)}{\partial X_{i}}=\beta\left[1-z \frac{f(z)}{F(z)}-\right. \\
& \left.\left(\frac{f(z)}{F(z)}\right)^{2}\right] . \quad \ldots \ldots \ldots \ldots \ldots \ldots \ldots \ldots \ldots \ldots . . .
\end{aligned}
$$

The two effects can be aggregated later to determine the total marginal effect as a result of a change in each individual explanatory variable.

Estimation for choice of seed source. The dependent variable in this analysis is defined by the type of seed source used by the smallholder in the kiremt season of 2012/13, which was also the season selected for the study. Farmers used a combination of three seed sources: (i) formal (formal seed source), (ii) informal (informal seed source) and (iii) CBSME. Given that farmers were at liberty to choose one, two or three out of the available seed sources, a multivariate Probit Model (MVP) was used to investigate the factors that facilitated or constrained bean producers who grew grain in these communities from choosing CBSME as their source of seed. A univariate model would leave out useful economic information about interdependence and simultaneous choice decisions.

We follow Teklewold et al. (2013) and specify a multivariate probit model for the choice of bean seed source by the Ethiopian bean growers as:

$C_{i j}^{*}=\alpha_{j} D_{i}+\varepsilon_{i j}$

$C_{i j}=1$ if $C_{i j}=C_{i j}^{*}$ and; -- where $j=$ formal,

informal or CBSME

$C_{i j}=0$ if Otherwise

Where:

Utility $\left(C_{i j}^{*}\right)$ is the latent variable determined by observed (i.e. household, market and institutional) characteristics cast in vector, $D_{i}$ and $C_{i j}$ is the observed dependent variable defined as the choice of seed source $j$ used by household $i$. Vector $\alpha_{j}$ consists of unknown parameter to be estimated while vector $\varepsilon_{i j}$ contains the unobserved characteristics associated with the choice $j$ made by the farmer $i$.

The unobserved characteristics were assumed to follow a multivariate normal distribution, with zero conditional mean and variance normalised to unity; $\varepsilon_{i j} \sim \operatorname{MVN}(0$, $\delta)$. The diagonal of the covariance matrix of $\varepsilon_{i j}$ are one, but what is useful are the non- zero off-diagonal elements of the matrix, which represent the unobserved correlation between the stochastic components of the different types of seed sources. 
Thus, by adopting MVP model, we are able to simultaneously determine the influence of the set of explanatory variables on the choice of each of the different seed source; while allowing the unobserved and/or unmeasured characteristics to be freely correlated. The correlation may be positive (complementary) or negative (substitute) between different seed sources.

Definition of explanatory variables. Variables included in the analysis were based on literature on adoption and seed enterprises, as well as documented information about the Ethiopian context (Bwire, 2008; Akinola et al., 2010; Alemu et al., 2011; Teferi, 2013). Empirical definitions of the explanatory variables and their descriptive statistics are presented in Table 1. Some of these variables were useful in testing the assumptions on positive complementarity of formal and CBSME regarding reach to users distinguished by wealth status and locations with respect to distance from main urban centre that underlie most interests in CBSMEs.
Household and farm characteristics. We included several characteristics of the household head (i.e. age, education, gender and occupation) and those of the household (i.e. household size and wealth assets). Gender of the household head captures the differences between household typologies with regard to resource endowments and type of social networks. Ethiopia is a patriarchal society that keeps women at a subordinate position while putting men at a comparative advantage in terms of accessing information, better pay and asset accumulation (Kassa, 2015). Such gender disparities in favour of men mean that men are more likely to learn about new business opportunities such as seed multiplication enterprises as well as purchase seed produced from CBSME as compared to women.

Age of the household head influences the accumulation of experience about seed quality that may be needed to participate in seed production and/or purchase seed from formal or CBSME. Younger individuals are also more likely to access information about new innovations, learn new skills needed in business

TABLE 1. Definition and summary statistics (standard deviation) of the variables used in the analysis

\begin{tabular}{lcrrl}
\hline Variable & $\begin{array}{c}\text { Total sample } \\
(\mathrm{N}=195)\end{array}$ & $\begin{array}{c}\text { Seed } \\
\text { multipliers } \\
(\mathrm{N}=50)\end{array}$ & $\begin{array}{c}\text { Grain } \\
\text { producers } \\
(\mathrm{N}=145)\end{array}$ & $\begin{array}{c}\text { t-value/ } \\
\text { chi-square }\end{array}$ \\
\hline Age (years) & 38.374 & $41.08(1.46)$ & $37.44(0.82)$ & $-2.21^{* *}$ \\
Formal education (years) & 4.64 & $5.04(0.39)$ & $4.49(0.24)$ & -1.16 \\
Family size (Adult equivalent) & 3.19 & $3.73(0.23)$ & $3.00(0.13)$ & $-2.87^{* * *}$ \\
Livestock (TLU) & 4.65 & $6.72(1.25)$ & $3.74(0.57)$ & $-2.79^{* * *}$ \\
Number of agricultural equipment & 10.94 & $14.44(1.79)$ & $9.74(0.46)$ & $-3.6^{* * *}$ \\
Land owned (ha) & 3.01 & $4.52(0.28)$ & $2.52(0.16)$ & $-6.24^{* * *}$ \\
Distance to main district town (Km) & 28.55 & $19.176(2.93)$ & $31.78(1.33)$ & $4.44^{* * *}$ \\
Distance to tarmac road (Km) & 9.19 & $2.77(0.63)$ & $11.41(3.56)$ & 1.42 \\
Price (US\$/kg) & 0.50 & $0.58(0.42)$ & $0.48(0.35)$ & $-3.15^{* * *}$ \\
Male headed household (\%) & 87.69 & 86.00 & 88.27 & 0.18 \\
Household participating in organization (\%) & 86.67 & 84.00 & 87.59 & 0.41 \\
Respondents with Access to credit (\%) & 47.69 & 60.00 & 43.45 & $4.08^{* *}$ \\
Households participating in Off-farm income (\%) & 0.33 & 0.16 & 0.39 & $9.09^{* * *}$ \\
Households using Agri-input (\%) & 93.33 & 96.00 & 92.41 & 0.768 \\
Households visited by Extension worker (\%) & 89.74 & 96.00 & 87.59 & $2.85^{*}$ \\
\hline
\end{tabular}

$*, * *$ and $* * *$ denote are significant variables at 10,5 and 1 percent level of significance, respectively 
and take risk (Salim 1986; Feleke and Zegeye, 2006; Chukwuji and Ogisi, 2006). Thus, the expected sign of age on participation in CBSME or choosing it as a source of seed cannot be determined a priori. Similarly, education of the household head is linked to participation in CBSME through information acquisition and processing (Schultz, 1975).

Household wealth, represented by landholding, livestock ownership and agriculture equipment was expected to positively influence participation in CBSME and the probability that a household chooses CBSME and formal seed sources over informal seed sources. Farmers with larger land sizes can overcome liquidity constraints and have low opportunity cost of land under experimentation (Shiyani et al., 2000; Bwire, 2008; Thapa, 2008; Sitomwe et al., 2009; Teferi, 2013). Similarly, possession of a larger number of different agricultural equipment (such as cart, sickle, axe, hoe, knapsack sprayer and water carrier) reflects the household capacity to undertake and complete agricultural activities, which in turn, may influence uptake of new innovations. Different livestock types (i.e. cattle, pig, sheep, goat, and poultry) owned by a household were combined into a single continuous measure using the Tropical Livestock Unit (TLU) and is expected that households endowed with large size of livestock are likely to overcome financial constraints and afford seed from formal or CBSME source.

Other household characteristics assumed to influence the likelihood that a household participates in CBSME and chooses formal and CBSME seed sources were access to credit, off-farm income and having membership in farmer organisations. Off farm income is linked to participation in CBSME through two mechanisms (i.e. purchasing power or opportunity cost) that operate in opposite directions, thus its expected sign is indeterminate. Farmer associations in Ethiopia represent a form of social capital for members to access NGOS involved in disseminating seed to farmers (Alemu et al., 2011).
Location and contextual factors. For contextual factors, proximity to town centers, presence of a market in the village and extension were included as proxies for market characteristics and information access. Households close to the district town were expected to face lower transaction costs involved in looking for a buyer of CBSME seed as well as that of acquiring initial seed for uptake of CBSME. On the other hand, households located in villages where a grain market is present were expected to face competition from the latter when selling their seed from CBSME and be discouraged from participating or obtaining seed from the CBSME. Contact with extension was expected to exert an influence on the access to information and skills necessary for started up of CBSME and choice of seed source (Feder et al., 1985; Asfaw et al., 2012).

\section{RESULTS AND DISCUSSION}

Profitability of CBSME. Results of gross margins obtained by bean farmers involved in the CBSME and those who produced bean as grain are presented in Table 2. The average total costs incurred by seed multipliers and grain producers were respectively, US $\$ 608.38$ and $334.94 \mathrm{ha}^{-1}$. The higher cost that accrued to seed multiplication through CBSME can be attributed to upward adjustment in input use by seed producers (Table 2 ).

Input adjustment for seed producers occurred in land quality, labour (especially during land preparation, weeding and sorting of seed) and amount of the DAP used. Because some farmers accessed land through renting, it was treated as a variable input unlike in Katungi et al. (2011), where the cost of land was treated as a fixed input.

Table 2 shows that the cost of land used for seed multiplication is valued at US\$200 per hectare and higher than that used for grain production (valued at US\$128 per hectare). The differences in the value of land could be because seed production is conducted on 
TABLE 2. Descriptive statistics of the production costs and revenue of sale of bean seed by CBSME and bean grain, Central Rift valley of Ethiopia

\begin{tabular}{|c|c|c|c|c|c|c|}
\hline \multirow[t]{2}{*}{ Description of the cost (US\$) } & \multicolumn{3}{|c|}{ Seed multiplication $(\mathrm{N}=50)$} & \multicolumn{3}{|c|}{ Grain production $(\mathrm{N}=157)$} \\
\hline & $\begin{array}{c}\text { Mean } \\
\left(\text { US\$ha }^{-1}\right)\end{array}$ & SD & $\%$ & $\begin{array}{c}\text { Mean } \\
\left(\text { US\$ha-1) }^{-1}\right)\end{array}$ & SD & $\%$ \\
\hline Total cost of land & 200.41 & 289.04 & 32.94 & 127.8 & 107.88 & 38.16 \\
\hline Cost of seed & 66.76 & 34.6 & 10.97 & 40.67 & 35.85 & 12.14 \\
\hline Total cost of Urea & 3.83 & 24.28 & 0.63 & 4.11 & 12.64 & 1.23 \\
\hline Total cost of DAP & 67.57 & 61.04 & 11.11 & 46.55 & 38.13 & 13.90 \\
\hline Total cost of paid labour & 86.66 & 116.94 & 14.24 & 48.23 & 71.45 & 14.40 \\
\hline Total cost of unpaid labour & 178.54 & 658.53 & 29.35 & 61.21 & 44.53 & 18.28 \\
\hline Total cost of anti-pest & 1.26 & 10.73 & 0.21 & 0.21 & 1.35 & 0.06 \\
\hline Total cost of storage & 0.07 & 0.02 & 0.01 & 0.02 & 0.24 & 0.01 \\
\hline Total cost of transport to individuals & 0.10 & 0.20 & 0.02 & 0.19 & 0.22 & 0.06 \\
\hline Total cost of transport to crop & 3.18 & 3.82 & 0.52 & 5.95 & 7.51 & 1.78 \\
\hline Total production cost & 608.38 & & 100.00 & 334.94 & & 100.00 \\
\hline revenue from crop sales & 1310.91 & 1367.61 & 93.59 & 936.23 & 850.61 & 93.74 \\
\hline Revenue from residue & 89.86 & 56.42 & 6.41 & 62.57 & 36.20 & 6.26 \\
\hline Total production revenue & 1400.76 & NA & 100.00 & 998.81 & NA & 100.00 \\
\hline Profit (US\$) & 792.38 & NA & NA & 663.87 & NA & NA \\
\hline Gross margin & 56.56 & NA & NA & 66.46 & NA & NA \\
\hline
\end{tabular}

$\mathrm{SD}=$ standard deviation; $\mathrm{NA}=$ Not applicable

higher quality land in terms of fertility. In the bean seed production manual (David, 1998), farmers are advised to select high quality land for seed production to enhance yields. Using such seed production manuals, seed producers are usually trained by development workers on relevant business plans and the required best practices for successful seed production (Tebeka, 2016), thus influencing the type of land used for seed production.

Nevertheless, per hectare cost of seed production incurred by seed multipliers was lower than expected, considering that certified seed is used, perhaps reflecting the fact that part of seed used in CBSME is recycled. The costs of labour and fertiliser were also higher among seed multipliers than grain producers.

Labour, which, is mainly contributed by the household members accounts for the highest share of the total costs; 44 percent for seed multipliers and 33percent for grain producers (Table 2). Increase in labour costs is both a reflection of the higher productivity of seed production plots that increases harvesting and post-harvest handling labour (Larochelle et al., 2015); as well as additional seed quality control practices used by seed producers. Seed producers have been reported to increase efforts on sorting out poor-quality seeds, including those that are visibly diseased (Rubyogo et al., 2009).

The total cost of fertiliser (US\$71.4) used in seed multiplication is higher than that used for grain (US\$50.7), which reflects differences in quantities used by the two groups. From Table 2, it can be deduced that an average seed multiplier used $60 \mathrm{~kg} \mathrm{ha}^{-1}$ of DAP and $3.83 \mathrm{~kg}$ $\mathrm{ha}^{-1}$ of urea; while a grain producer used 46.55 $\mathrm{kg} \mathrm{ha}^{-1}$ of DAP and $4.11 \mathrm{~kg} \mathrm{ha}^{-1}$ of urea.

The cost of marketing included transport and packing (Table 2). However, these costs were dismal, accounting for just 0.54 and 1.84 percent of the total costs incurred by seed multipliers and grain producers, respectively. Transport costs are insignificant because most of the seed multipliers made transactions at 
the farm gate; the average cost of storage accounted for only 0.01 percent of the total cost.

Table 2 also shows the total revenue from the sales of seed or grain and residue from bean crop. Combining the crop and residue sales, the respective per hectare total revenue for seed multipliers and grain producers were US\$1400.76 and US\$998.81. The average selling price for seed was US $\$ 0.58 \mathrm{~kg}^{-1}$, statically higher than the price of grain US $\$ 0.48 \mathrm{~kg}^{-1}$ in the same season (Table 1). Producers who sold seed late during the sowing period received as high as US $\$ 0.9 \mathrm{~kg}^{-1}$ compared to those who sold immediately after harvest (US\$0.3 $\mathrm{kg}^{-1}$ ). Also, selling to organisations such as MARC and the Catholic Missionary Church, attracted a higher price compared to selling directly to fellow farmers. The NGOs involved in seed dissemination also purchase seed in bulk at fixed prices; thus greatly influencing the revenue received (Alemu, 2015).

Comparing the average total revenue with the average total variable costs gave US\$792.38 $\mathrm{ha}^{-1}$ as average gross margins for seed multiplication and US $\$ 663.87 \mathrm{ha}^{-1}$ as gross margins for grain production. The gross margins for seed multipliers were higher than those of grain producers by US $\$ 128.51 \mathrm{ha}^{-1}$. In relative terms, the profit margins from seed production constituted 56.57 percentof revenue, which were much higher than 36 percent reported for Kenya in 2011 (Katungi et al., 2011); but lower than that received from grain production (66.46 percent) in the study area (Table 2).

The difference in revenue between seed producers and grain producers emanates from differences in selling price received; as well as yields associated with better management by the former. Accordingly, there was a difference of US\$511 in revenue between seed producers and grain producers, which was much higher than the respective difference between production costs (US\$273). This is evidence that though seed multiplication is accompanied by increase in production costs, it is profitable when farmers gain skills in good management for seed production and the incentives in form of higher prices. However, producers who sold seed as grain benefited dismally, which is an indication that the performance of CBSME depends on the proportion of harvest that is marketed as seed. Thus, it is important to expand the demand for seed produced by CBSME for future sustainability of the model.

Farmers' participation in CBSME._Results from the Tobit estimation are presented in Table 3. The F-test statistic value of 4.55 (significant at $1 \%$ level), confirms that the variables included in the model jointly explained variations in the CBSME participation decisions within the sample.

Results reveal that the smallholders' decisions to participate and their intensity of participation were determined by a number of factors, namely: sex of the household head, education of the household head, agricultural equipment possessed by the household, off farm income and land size (Table 3). Contrary to our expectations, participation in CBSME was higher among female-headed households than among their male counterparts. This result reflects the fact that under the CBSME project, there were efforts to increase women participation, which could have contributed to higher chances of the female-headed households participating in CBSME.

Education level positively influenced the size of land allocated to seed multiplication, but had no significant influence on the probability of participation in CBSME (Table 3). An increase in the formal education by one year increased the amount of land allocated to seed multiplication by 0.08 ha. This is perhaps because education increases the individuals' ability to access and process information and might increase their profits from seed (Teklewold et al., 2006; Foster and Rosenzweig, 2010).

Wealthier households in terms of land size and agriculture equipment were more likely to participate in seed multiplication, allocating 
TABLE 3. Factors affecting participation in seed multiplication and amount of land allocated to it among smallholder producers in the Central Rift valley, Ethiopia

\begin{tabular}{|c|c|c|c|}
\hline Variable & Coefficient & $\begin{array}{c}\text { Change in probability } \\
\text { of participation }\end{array}$ & $\begin{array}{l}\text { Change in land } \\
\text { allocated }\end{array}$ \\
\hline Sex of household head (1=male) & $\begin{array}{l}-0.937 * * \\
(0.456)\end{array}$ & $\begin{array}{l}-0.061 * * \\
(0.029)\end{array}$ & $\begin{array}{l}-0.228 * * \\
(0.112)\end{array}$ \\
\hline Age of household head & $\begin{array}{c}0.0106 \\
(0.019)\end{array}$ & $\begin{array}{c}0.001 \\
(0.001)\end{array}$ & $\begin{array}{c}0.003 \\
(0.005)\end{array}$ \\
\hline Education in years & $\begin{array}{c}0.075^{*} \\
(0.044)\end{array}$ & $\begin{array}{c}0.005 \\
(0.003)\end{array}$ & $\begin{array}{c}0.018 * \\
(0.011)\end{array}$ \\
\hline Family size & $\begin{array}{c}0.007 \\
(0.114)\end{array}$ & $\begin{array}{c}0.001 \\
(0.007)\end{array}$ & $\begin{array}{c}0.002 \\
(0.028)\end{array}$ \\
\hline Total livestock unit & $\begin{array}{c}0.036 \\
(0.023)\end{array}$ & $\begin{array}{c}0.002 \\
(0.002)\end{array}$ & $\begin{array}{c}0.009 \\
(0.006)\end{array}$ \\
\hline Farm size & $\begin{array}{l}0.336 * * * \\
(0.095)\end{array}$ & $\begin{array}{l}0.022 * * * \\
(0.005)\end{array}$ & $\begin{array}{l}0.082^{* * * *} \\
(0.024)\end{array}$ \\
\hline Distance to village market(Km) & $\begin{array}{c}0.065 \\
(0.053)\end{array}$ & $\begin{array}{c}0.004 \\
(0.004)\end{array}$ & $\begin{array}{c}0.016 \\
(0.012)\end{array}$ \\
\hline Membership in cooperative & $\begin{array}{l}-1.110^{* * * *} \\
(0.367)\end{array}$ & $\begin{array}{l}-0.073 * * * \\
(0.026)\end{array}$ & $\begin{array}{l}-0.270^{* * * *} \\
(0.084)\end{array}$ \\
\hline Extension & $\begin{array}{c}0.938 \\
(0.741)\end{array}$ & $\begin{array}{c}0.061 \\
(0.052)\end{array}$ & $\begin{array}{c}0.228 \\
(0.179)\end{array}$ \\
\hline Access to credit & $\begin{array}{c}0.386 \\
(0.261)\end{array}$ & $\begin{array}{c}0.025 \\
(0.016)\end{array}$ & $\begin{array}{c}0.094 \\
(0.062)\end{array}$ \\
\hline Off-farm income (1=yes) & $\begin{array}{l}-0.937 * * \\
(0.361)\end{array}$ & $\begin{array}{l}-0.062 * * * \\
(0.021)\end{array}$ & $\begin{array}{l}-0.22819^{* *} \\
(0.088)\end{array}$ \\
\hline Agriculture equipment index & $\begin{array}{l}0.047 * * * \\
(0.015)\end{array}$ & $\begin{array}{l}0.003 * * * \\
(0.001)\end{array}$ & $\begin{array}{l}0.012 * * * \\
(0.004)\end{array}$ \\
\hline $\begin{array}{l}\text { _constant } \\
\text { /sigma }\end{array}$ & $\begin{array}{l}-3.079 * * * \\
1.355\end{array}$ & & \\
\hline Number of observations & 195 & & \\
\hline Pseudo R2 & 0.243 & & \\
\hline $\mathrm{F}(12,183)$ & 4.55 & & \\
\hline Prob $>$ F & 0 & & \\
\hline
\end{tabular}

Numbers in parentheses are standard errors. *,** and $* * *$ are significant variables at 10,5 and 1 percent level of significance, respectively 
larger land than poorer ones (Table 3). For one hectare increase in land holding, the probability that a household decided to participate in seed multiplication increased by 2.2 percent and the land allocated to the enterprise increased by 0.08 ha, respectively. The results are consistent with findings in the study conducted by Welelign (2008), which reported a significant and positive effect of land size on the household participation in farmer-based seed multiplication for a number of crops in the Southern region of Ethiopia. Similarly, the number of agricultural equipment had a positive and significant association with the probability that a bean producer decided to participate in seed multiplication and was found to increase the amount of land allocated to the seed multiplication (Table 3). Both results reflect the fact that the success in seed multiplication requires resources that might be limiting among majority of bean producers. For example, results show that grain producers owned about 2.25 ha and 9.74 agriculture equipment, which was much lower than respective land size (4.25 ha) and agriculture equipment (14.44) owned by seed producers (Table 1). This is suggestive that some grain producers who have not joined the CBSME model might be resource constrained. As observed by Bahadur (2004), resource constrained farmers are generally driven by food security objectives and might not respond to profitable opportunities.

Results also demonstrated that membership to organisations (such as cooperatives) is negatively associated with participation in seed multiplication. Being a member to organisations decreased the probability of participating in seed multiplication by $7.3 \%$; while land allocated to the activity decreased by 0.27 ha. This is possibly because smallholders who participated in cooperatives and farmer organisations easily accessed improved seed compared to the ones who did not participate. Since cooperatives and farmer unions occasionally distributed free seed including that from the CBSME in Ethiopia (Alemu et al., 2011), members might have been discouraged from taking up seed multiplication as a private investment. This is evidence that NGOs that use farmer organisation networks as outlets for seed distribution (Alemu, 2015) crowd out the private participation in CBSME.

Having off-farm income was also negatively related with participation in seed multiplication and allocation of land to the activity (Table 3 ). The probability of participation in seed multiplication decreased by $6.2 \%$ when a respondent had an off-farm income. The amount of land allocated also decreases by 0.23 ha for those with off-farm income. This was perhaps associated with higher opportunity cost of time for individuals employed off-farm since CBSME members underwent intensive training and monitoring by public actors such as Research Organisations and/or, NGOs (Welu, 2015). Compared to grain producers (39 percent), seed multipliers were more dependent on farming, with only 16 percent participating in off-farm income activities (Table 1). Household heads who are involved in off-farm income might face high opportunity cost of time when required to attend training and meetings on seed production techniques supported under the project (Rubyogo et al., 2016)

Choice of seed source demand-side of the seed system. Results indicate that the three sources of bean seed (formal, informal and CBSME) were used and that majority of bean growers in the study area simultaneously used more than one seed source (Fig. 1).

As expected, formal seed sources were prevalent among seed multipliers, and were used by 88 percent of interviewed seed multipliers. However, only 32 percent of seed multipliers exclusively planted seed from the formal seed sources; while 46 percent of the seed multipliers combined seed from the formal sources with seed from their previous harvest (Fig. 1).

A large number of grain producers used multiple sources (i.e. formal, informal and the community based seed multipliers) to meet 


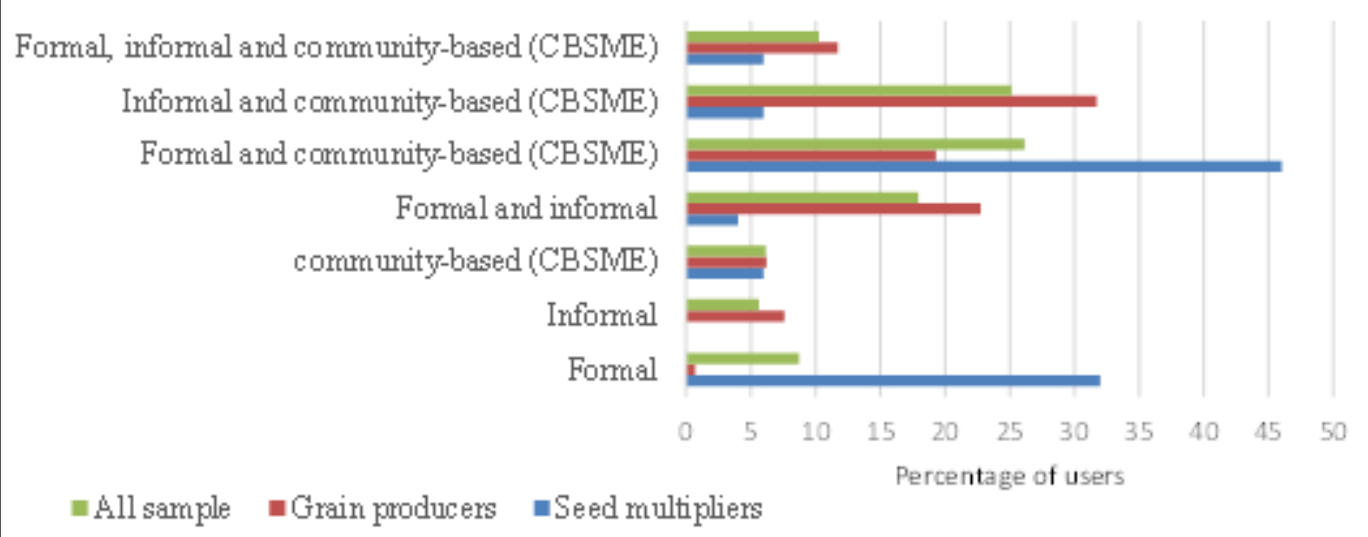

Figure 1. Proportion of farmers by seed source during 2012/13 kiremt production season in Central Rift valley of Ethiopia.

their seed demand (Fig. 1). The most popular combination of seed sources by this group was the informal+ CBSME (31.72\%); followed by formal plus informal; used by 23 percent of the grain producers.

Choice of seed source. Factors that influence the choice of seed source together with the Wald test results, are presented in Table 4. Based on this diagnostic result, the null hypothesis of all coefficients in each equation being jointly equal to zero could not be accepted. The likelihood ratio test of the null hypothesis that there is no correlation between the error terms across equations was also rejected $\left(\chi^{2}(3)=42.9947\right.$, Prob $>\chi^{2}=$ $0.0000)$, which means that the alternative seed sources were not mutually exclusive. This confirms that a multivariate probit model was a suitable specification for the data analysis.

The model revealed a substitution effect between seed sources, with the formal and CBSME showing a relatively stronger negative correlation of 0.52 , which implies that the two seed sources were close substitutes. On the other hand, the correlation between formal and informal was weak, $(-0.443)$, perhaps because farmers tended to keep some grain from the previous harvest as supplement to the formal source. For the same reasons, the correlation between informal and CBSME as source was observed to be weak (-0.243), but significant.

Results revealed that household characteristics as well as market access conditions influenced the seed source used by bean growers in the study area (Table 4). Older farmers were less likely to access seed from the formal seed source perhaps because as farmers advance in age, they devise effective methods for controlling quality of their own bean seed (Asfaw et al., 2013) and develop trust in their own seed over other sources (CRS, 2014). This suggests that the perceived benefit of bean seed from formal sources might be lower for older farmers, which implies that targeting younger farmers for promoting formal sources will be more effective in resource use while creating longer term growth in demand for bean seed from formal sources.

Households with larger landholdings were more likely to choose a formal seed source over informal seed sources compared to those with smaller landholding (Table 4). In particular, results indicate that when the household landholding increased by one hectare, the probability that the producer would choose the formal sources of bean seed for planting increased by 15.8 percent; while that of choosing informal seed source reduced by 
TABLE 4. Multivariate estimation of the factors affecting the choice of seed source by bean grain producers, Rift Valley of Ethiopia

\begin{tabular}{|c|c|c|c|}
\hline Variables & Formal & Informal & Farmers based \\
\hline Sex of $\mathrm{HH}^{\wedge}$ & $0.383(0.357)$ & $0.272(0.357)$ & $0.199(0.338)$ \\
\hline Age of $\mathrm{HH}^{\wedge}$ & $-0.028 *(0.015)$ & $0.022(0.014)$ & $0.020(0.015)$ \\
\hline Formaleducation of $\mathrm{HH}^{\wedge}$ & $-0.023(0.031)$ & $0.032(0.031)$ & $-0.039(0.032)$ \\
\hline Family size inadultequivalent & $0.073(0.087)$ & $-0.015(0.083)$ & $-0.033(0.084)$ \\
\hline Livestock (TLU) & $0.003(0.015)$ & $-0.001(0.015)$ & $-0.009(0.014)$ \\
\hline Farmsize (ha) & $0.158^{* * *}(0.058)$ & $-0.231 * * *(0.058)$ & $0.021(0.057)$ \\
\hline Participation in organization & $-0.073(0.319)$ & $-0.540(0.375)$ & $1.715 * * *(0.347)$ \\
\hline Extension visit & $-0.007(0.008)$ & $-0.004(0.008)$ & $0.014 *(0.008)$ \\
\hline Credit Access & $-0.133(0.221)$ & $0.115(0.217)$ & $0.083(0.216)$ \\
\hline Distance to district town $(\mathrm{Km})$ & $-0.029 * * *(0.007)$ & $0.010(0.006)$ & $0.014 * *(0.007)$ \\
\hline Participation in off-farm income & $0.149(0.209)$ & $0.198(0.212)$ & $0.079(0.212)$ \\
\hline cons & $0.902(0.642)$ & $0.303(0.661)$ & $-1.996 * * *(0.670)$ \\
\hline rho21 & & $-0.443 * * *$ & \\
\hline rho31 & & $-0.521 * * *$ & \\
\hline rho32 & & $-0.243 * *$ & \\
\hline Number of observations & & 195 & \\
\hline Wald chi2(39) & & 96.06 & \\
\hline Prob > chi 2 & & 0.000 & \\
\hline Log likelihood & & -299.83604 & \\
\hline
\end{tabular}

Likelihood ratio test of rho2 $1=$ rho3 $=$ rho32 $=0: \operatorname{chi} 2(3)=42.99$ Prob $>$ chi $2=0.00 ;{ }^{\wedge} \mathrm{HH}=$ Household head $*$, ** and $* * *$ denote significant variables at 10,5 and 1 percent level respectively; Parenthesis are standard errors

23.1 percent (Table 4). Landholding is a surrogate for risk taking, access to information and credit, all of which are positively associated with adoption of new innovations (Feder et al., 1985; Foster and Rosenzweig, 2010).

Neither, wealth nor education showed a significant effect on use of CBSME as the source of seed for bean (Table 4), suggesting that this type of seed source was neutral to social status. The poorer as well as the wealthier households, used CBSME. Similarly, households headed by less educated individuals and those headed by highly educated individuals were equally likely to choose CBSME as their source for seed.

Participation in Organisations, such as cooperatives, significantly influenced the choice of seed source (Table 4). Households who were members to organisations were likely to choose CBSME as the source for their seed requirements. Organisations serve as information hubs and the channel for distribution of seed from CBSME (Rubyogo et al., 2016). Similarly, extension visits help to reinforce the message and popularise the new innovations (Oladele, 2005). Since NGOs that are heavily involved in the distribution of seed from CBSME, also employ extension to provide training in general seed production (Alemu, 2015), it is also possible that NGOS supplied seed to their farmers along with information.

Market conditions represented in the analysis by distance to main district town were negatively related with use of formal seed source (Table 4). As expected, farmers who were far from the district (woreda) town were less likely to use formal seed sources due to limited accessibility. Most agro-input dealers, including Ethiopian Seed enterprise, were located in the main towns; meaning that rural based farmers who were far from district 
(woreda) towns incurred higher transport costs to access seed (Minten et al., 2013). On the other hand, distance from town to the village exerted a positive influence on the probability that a farmer would choose from CBSME. It was evident that the two models complemented each other in terms of geographical reach.

\section{ACKNOWLEDGMENT}

The authors are grateful for the financial support provided for this study by the Government of Ethiopia through EIARMelkassa, Bill \& Melinda Gates Foundation through Tropical Legume II Project, Swiss Agency for Development and Cooperation (SDC) and Global Affairs Canada (formerly Canadian International Development Agency [CIDA]) through the Pan-Africa Bean Research Alliance (PABRA)/CIAT and the Eastern and Central Africa Bean Research Network (ECABREN).

\section{REFERENCES}

Akinola, A.A., Alene, D.A., Adeyemo, R., Sanogo, D., Olanrewaju, A. S., Nwoke, C. and Nziguheba, G. 2010. Determinants of adoption and intensity of use of balance nutrient management systems technologies in the northern Guinea savanna of Nigeria. Quarterly Journal of International Agriculture 4(1):25-45.

Alemu, D. 2011. Farmer-based seed multiplication in the Ethiopian seed system: Approaches, priorities \& performance. Future Agricultures Consortium (FAC) Working Paper \#36, Future Agricultures Consortium, Brighton.

Alemu, K. 2015. Seed production and dissemination systems analyses: The case of Ethiopia.

Food Science and Quality Management. https/ www.iiste.org_ISSN 2225-0557 (Online) 35.

Amare, M., Asfaw, S. and Shiferaw, B. 2012. Welfare impacts of maize-pigeonpea intensification in Tanzania. Agricultural Economics 43: 27-43.

Asfaw, S., Shiferaw, B., Simtowe, F. and Lipper, L. 2012. Impact of modern agricultural technologies on smallholder welfare: Evidence from Tanzania and Ethiopia. Food Policy 37(3): 283-295.

Asfaw, A., Almekinders, M., Struik, C. and Blair, W. 2013. Farmers' common bean variety and seed management in the face of drought and climate instability in southern Ethiopia. Academic Journals: 1022-1037.

Bahadur, K.L. 2004. Technology adoption and household food security. Analysing factors determining technology adoption and impact of project intervention: A case of smallholder peasants in Nepal. Paper prepared to present in The Deutscher Tropentag held on 5 - 7 October, 2004, Humboldt-University, Berlin.

Bernard, M., Hellin, J., Nyikal, R. A. and Mburu, J. G. 2010. Determinants for use of certified maize seed and the relative importance of transaction costs. In: 2010 AAAE Third Conference/AEASA 48th Conference, September 19-23, 2010, Cape Town, South Africa (No. 96423). African Association of Agricultural Economists (AAAE) \& Agricultural Economics Association of South Africa (AEASA).

Buruchara, R., Chirwa, R., Sperling, L., Mukankusi, C., Rubyogo, J.C., Muthoni, R. and Abang, M. M. 2011. Development and delivery of bean varieties in Africa: the Pan-Africa Bean Research Alliance (PABRA) model. African Crop Science Journal 19(4):227-245.

Bwire, J. 2008. Factors affecting adoption of improved meat goat (boer) production in rangelands of Sembabule district. Msc. Thesis, Makerere University Kampala, Uganda. 68pp.

CRS. 2014. Introduction - Improved seed storage briefs. Nairobi: Catholic Relief Services.

Chukwuji, C.O. and Ogisi, D.O. 2006. A Tobit analysis of fertiliser adoption by smallholder 
cassava farmers in Delta State, Langyintuo, A.S., Mwangi, W., Diallo, A.O., Nigeria. Agricultural Journal 4: 240-248. MacRobert, J., Dixon, J. and Bänziger, M.

Crawford, E., Kelly, V., Jayne, T.S. and Howard, J. 2003. Input use and market development in Sub-Saharan Africa: an overview. Food Policy 28(4): 277-292.

David, S. 1998. Producing bean seed: handbooks for small-scale bean producers. Handbook 1. Network on Bean Research in Africa, Occasional Publications Series, No. 29. CIAT, Kampala, Uganda.

Feder, G., Just, R.E. and Zilberman, D. 1985. Adoption of agricultural innovations in developing countries: A survey, Economic Development and Cultural Change 33(2):255-298.

2010. Challenges of the maize seed industry in eastern and southern Africa: A compelling case for private-public intervention to promote growth. Food Policy 35(4): 323331.

Larochelle, C., Alwang, J., Norton, G.W., Katungi, E. and Labarta, R.A. 2015. Impacts of Improved Bean Varieties on Poverty and Food Security in Uganda and Rwanda. In: Walker TS, Alwang J, editors. Crop Improvement, Adoption and Impact of Improved Varieties in Food Crops in SubSaharan Africa: CAB International 2015. pp. 314-37.

Feleke, S. and Zegeye, T. 2006. Adoption of improved maize varieties in Southern Ethiopia: Factors and strategy options. Food Policy 31(5): 442-457.

Foster, A. D. and Rosenzweig, M. R. 2010. Microeconomics of technology adoption. Annual Review of Economics 1 (2): 395424. doi: 10.1146/annurev.economics. 102308.124433.

Funte, S.,Negesse, T. and Legesse, G. 2010. Feed resources and their management systems in Ethiopian highlands: the case of UmbuloWacho watershed in southern Ethiopia. Tropical and Subtropical Agroecosystems 12 (1):47-56.

Gujarati, D.N. 2004. Basic econometrics fourth edition McGraw-Hill, New York. pp. 342-375

Habte, E., Gebeyehu, S., Tumsa, K. and Negash, K. 2011. Decentralised Common Bean Seed Production and Delivery System. Farmers' Access to Seed 61.

Kassa, C. 2015. Challenges and opportunities of women political participation in Ethiopia.

Journal of Global economics. 3:165. doi:10.4172/2375-4389.1000162

Katungi, E.,Wozemba, D. and Rubyogo, J. C. 2011. A cost benefit analysis of farmer based seed production for common bean in Kenya. African Crop Science Journal 19(4): 409-415.

Maddala, G.S. 1983. Limited-dependent and qualitative variables in econometrics. Cambridge University Press, New York, USA.

Minten, B., Koru, B. and Stifel, D. 2013. The last mile (s) in modern input distribution: Pricing, profitability, and adoption, Agricultural Economics 44: 629-646.

Oladele, O.L. 2005. A Tobit Analysis of propensity to continue adoption of agricultural technology among farmers in South Western Nigeria. Journal of Central European Agriculture (3):249-254

PABRA database. 2015. http://database. pabraafrica.org/?location=breeding \& locId=211 Accessed on May, 2015.

Rubyogo, J.C., Gebeyehu, S., Tumsa, K., Negash, K., Habte, E., Katungi, E. and Wozemba, D. 2011. Increased bean productivity through increased access to improved seeds and use of improved bean management techniques in Ethiopia. In: Conference "Increasing Agricultural Productivity and Enhancing Food Security in Africa. pp. 1-3.

Rubyogo, J.C., Sperling, L., Muthoni, R. and Buruchara, R. 2010. Bean seed delivery for small farmers in Sub-Saharan Africa: The power of partnerships. Society and Natural Resources 23(4): 285-302. 
Rubyogo, J.C., Sperling, L., Nasirumbi, L. and Kasambala, S. 2007. Developing seed systems with and for the marginalised: Case of common bean (Phaseolus vulgaris L.) in East, Central and Southern Africa. In Proceedings of Farmer First Revisited Conference, Sussex, UK. pp. 12-14.

Rubyogo, J.C., Dickinson, M., Mayes, S. and Assefa, T. 2009. Seed health assessment of bean seed grades and sources from Ethiopia using molecular tools. Journal of New Seeds 10(4:) 293-310.

Rubyogo, J.C., Myers, M., Ajeigbe, H., Kamara, A., Boahen, S., Buruchara, R., Upadhyaya, H., Pasupuleti, J., Okori, P., Desmae, H. 2016. Integrated seed systems delivering on the promise: Experiences from tropical legumes II. In: Monyo E.S. and Varshney, R.K. (Eds.): Seven seasons of learning and engaging smallholder farmers in the drought-prone areas of sub-Saharan Africa and South Asia through tropical legumes. pp. 167-179. ICRISAT, Panthancheru, India.

Schultz, T. 1975. The value of the ability to deal with disequilibria. Journal of Economic Literature 13 (3):827-46.

Salim, M. 1986. Rural Innovation in Agriculture.Chugh Publications, India.

Shiyani, R.L., Joshi, P.K. Asokan, M. and Bantihan, M.C.S.2000. Adoption of improved chichpea varieties: Evidences from tribal region of Gujarati. Indian Journal of Agricultural Economics. 5(2): 160-171.

Simtowe, F., Zeller, M. and Diagne, A. 2009. The impact of credit constraints on the adoption of hybrid maize in Malawi. Review of Agricultural and Environmental Studies 90(1):5-22.

Tebeka, Y.A. 2016. Prospect and Profitability of farmers based common bean multiplication in Ethiopia: The case of Southern rift valet. An msc thesis, department of agribusiness and Resource Economics, Makerere University, Kampala, Uganda.
Teferi, T. 2013. Adoption of improved sorghum varieties and farmers' varietal trait preference in kobo district, northwolo zone, Ethiopia. Haramaya universuty, Dire Dawa, Ethiopia.

Teklewold, H., Kassie, M. and Shiferaw, B. 2013. Adoption of Multiple Sustainable Agricultural Practices in Rural Ethiopia. Journal of Agricultural Economics 64(3): 597-623.

Teklewold, H., Dadi,L., Yami, A. and Dana, N. 2006. Determinant of adoption of poultry technology: Double-hurdle approach, Debrezeit Agricultural Research Center, Debrezeit, Ethiopia.

Teshale, A., J.C. Rubyogo, L. Sperling, B. Amsalu, T. Abate, A. Deressa, F. Reda, R. Kirkby, and R. Buruchara. 2006. Creating partnerships for enhanced impact; Bean variety delivery in Ethiopia. J. Crop Sci. Soc. Ethiopia 12: 27-30.

Thapa, S. 2008. Adoption of improved seeds and inorganic fertilisers in Nepal.

Thijssen, M.H., Bishaw, Z., Beshir, A. and de Boef, W.S. 2008 (Eds.). Farmers, seeds and varieties: supporting informal seed supply in Ethiopia. Wageningen, Wageningen International. 348pp.

Tobin, J. 1958. Estimation of relationships for limited dependent variables. In: Econometrica 26 (1): 26-36.

Upton, M. 1964. A development of gross margin analysis. Journal of Agricultural Economics, 16: 111-117. doi:10.1111/ j.1477-9552.1964.tb00484.x

Walelign, G. 2008. Determinants and Role of farmers's seed and seedling multiplication in the SNNP region seed system. Msc. Thesis, School of Graduate Studies, Haramaya, University, Ethiopia.

Welu, G. 2015.Challenges and opportunities of seed multiplication in Eastern Tigray Ethiopia. Journal of Biology, Agriculture and Healthcare www.iiste.org ISSN 2225093X: 5(3). 